\title{
Health Assessment of Raptors in Triage in Belo Horizonte, Mg, Brazil
}

\section{-Author(s)}

Andery $D$ de $A^{1}$,

Ferreira Junior $\mathrm{FC}^{1}$,

Araújo AV de',

Vilela DA da $\mathrm{R}^{2}$

Marques MVR',

Marin SY ${ }^{1}$

Horta RS',

Ortiz MC1,

Resende JS de ${ }^{1}$

Martins NR da $S^{1, *}$

Avian Diseases Laboratory, Setor de Doenças das Aves, Departamento de Medicina Veterinária Preventiva, Escola de Veterinária da UFMG, Av. Antônio Carlos 6.627 - Caixa Postal 567, CEP 30123-970, Belo Horizonte, MG, Brazil

2 Instituto Brasileiro de Meio Ambiente e Recursos Naturais Renováveis, IBAMA, Avenida do Contorno, 8121, CEP 30.110120, Belo Horizonte, MG, Brazil

\section{-Mail Adress}

* Corresponding author e-mail address Nelson Rodrigo da Silva Martins

E-mail: nrsmart@gmail.com

\section{घKeywords}

Cathartiformes health, falcon, Falconiformes health, hawk, owl, raptors, Strigiformes health, vulture.

\section{ABSTRACT}

Falconiformes $(n=82)$, Strigiformes $(n=84)$ and Cathartiformes $(n=14)$ at a triage center (CETAS-Belo Horizonte, IBAMA, Brazil) were examined between 2008 and 2010 . No bird was reactive at hemagglutinationinhibition (HI) for antibodies against Mycoplasma gallisepticum (Mg). Two Caracara plancus (2/68) had HI titers (16-32) against Newcastle disease virus. No Chlamydophila psittaci DNA was detected in the liver $(P C R ; n=95)$. Blood smears (Giemsa; $n=89$ ) and spleen fragments ( $P C R$; $\mathrm{n}=82$ ) were $13.5 \%$ and $8.5 \%$ positive, respectively, for Haemoproteus only. Necropsy of Cathartiformes $(n=10)$, Falconiformes $(n=42)$ and Strigiformes $(n=57)$ showed that trauma injuries were the main cause $(63.3 \%)$ of admission and death, being fractures $(38.5 \%)$ of the thoracic limbs $(57.1 \%)$ the most frequent. Nematode $(12.8 \%)$, cestode $(1.8 \%)$, trematode $(0.9 \%)$, and acanthocephalan $(2.7 \%)$ parasite infections were relevant. Mites (Acari) were the most frequent (17.4\%) external parasites, particularly Ornithonyssus sylviarum in Asio clamator and Amblyomma cajennense in Tyto alba. Chewing lice (10.1\%) and Pseudolynchia spp. $(9.2 \%)$ were also found. Histomonas spp. (6.4\%) was found in the ceca of Bubo virginianus, Athene cunicularia, Tyto alba, and Asio clamator, but not in Falconiformes or Cathartiformes. Trichomonas spp. (oral cavity, pharynx and upper esophagus; 9.1\%) was detected in Falconiformes and Strigiformes, but not in Cathartiformes. Trichomonas spp. were found in A. cunicularia, Asio clamator, Glaucidium brasilianum and Tyto alba (Strigiformes), and in Rupornis magnirostris, Milvago chimachima, Falco femoralis, Falco sparverius and Caracara plancus (Falconiformes). Coccidia (9.1\%) (Sarcocystis spp., 6.4\%) and mycosis were observed in most Tyto alba (70\%). The evaluated Orders may not pose risks for commercial poultry production. Habitat loss and urban adaptation may be increasingly affecting raptors.

\section{INTRODUCTION}

Raptors are carnivorous birds of predatory habits, and are essential for population regulation because they are at the end of the food chain. They are also considered potential disease amplifiers and pathogen carriers. The Order Strigiformes is represented mostly by nocturnal owls. Falconiformes includes diurnal birds of prey, such as eagles, hawks, and falcons. The single family of Cathartiformes (Cathartidae) includes vultures, which are scavengers and which classification as bird of prey varies among authors. Despite not presenting determined adaptations for hunting, for practical reasons, especially due to their proximity to poultry farms, vultures were included in this study.

Brazil is known for its outstanding biodiversity; however, the intensification of human activities, such as the expansion of cities and the increasing demands for farming, generate strong pressure on the 
various biomes, leading to habitat loss, fragmentation and degradation (ICMBio, 2008). The main threats to the survival of populations of birds of prey are related to these human activities, as well as hunting, trafficking, superstition, persecution, and conflict with humans (ICMBio, 2008).

Conservation threats make it an urgent priority the determination of the occurrence, incidence and distribution of diseases in raptors. Few diseases of birds of prey kept in captivity are well documented, but little is reported on free-living raptors (Joppert, 2007). Serological studies show that free-living birds are exposed to pathogens through contact with poultry waste and runoff from farms, or by ingestion of contaminated carcasses (Höfle et al., 2002), being first victims, then potential sources.

Public and private institutions are responsible for receiving and maintaining rescued wild birds, including triage centers for wild animals (CETAS) rescued from trafficking or illegal captivity. Birds of prey account for $1-2 \%$ of all birds received by CETAS Belo Horizonte/MG (CETAS/BH). In the present study, we analyzed raptors received at CETAS/BH between December 2008 and
August 2010, with the objective of describing the general health of these birds and the main diseases that may threat the commercial poultry production.

\section{MATERIALS AND METHODS}

\section{Birds}

Birds of orders Falconiformes, Strigiformes and Cathartiformes submitted to CETAS-BH (IBAMA) $\left(\mathrm{S} 19^{\circ} 55^{\prime} \mathrm{W} 43^{\circ} 57^{\prime}\right)$, were analyzed in the period between December 2008 and August 2010. In total, 180 raptors, including 82 Falconiformes, 84 Strigiformes, and 14 Cathartiformes (Table 1), were evaluated.

\section{Necropsy}

Birds that died or were euthanized because they were suffering or it was clinically indicated due to the severity their injuries, were submitted to necropsy, according to a previously described protocol (Matushima, 2007). All necropsied birds were inspected to identify their species, origin, and injuries, such as fractures.

One hundred and nine $(n=109)$ birds were necropsied. Seventeen sick birds eventually died and

Table 1 - Raptor avian species studied, tests performed and results.

\begin{tabular}{|c|c|c|c|c|c|c|c|}
\hline Species & $\begin{array}{c}\text { Total } \\
(\mathrm{N})\end{array}$ & Necropsy & Blood smear $^{1}$ & PCR/ spleen ${ }^{2}$ & $\begin{array}{l}\mathrm{SAT} / \\
\mathrm{Mg}^{3}\end{array}$ & APMV-1/HI ${ }^{4}$ & $\begin{array}{c}\text { PCR/ } \\
C p^{5}\end{array}$ \\
\hline Falconiformes & 82 & & & & & & \\
\hline Buteo albicaudatus & 3 & 1 & $0 / 2$ & $0 / 1$ & $0 / 1$ & $0 / 2$ & $0 / 1$ \\
\hline Buteo brachyurus & 2 & 2 & $1 / 2$ & $0 / 2$ & $0 / 2$ & $0 / 2$ & $0 / 2$ \\
\hline Caracara plancus & 26 & 11 & $1 / 16$ & $0 / 11$ & $0 / 12$ & $2 / 13$ & $0 / 11$ \\
\hline Falco femoralis & 3 & 1 & $0 / 2$ & $0 / 0$ & $0 / 2$ & $0 / 1$ & $0 / 1$ \\
\hline Falco rufigularis & 1 & 0 & $0 / 1$ & $0 / 0$ & $0 / 1$ & $0 / 1$ & $0 / 1$ \\
\hline Falco sparverius & 8 & 5 & $0 / 1$ & $0 / 3$ & $0 / 2$ & $0 / 1$ & $0 / 4$ \\
\hline Heterospizias meridionalis & 1 & 0 & $0 / 2$ & $0 / 0$ & $0 / 1$ & $0 / 1$ & $0 / 1$ \\
\hline Leptodon cayanensis & 2 & 2 & $0 / 0$ & $0 / 1$ & $0 / 2$ & $0 / 1$ & $0 / 1$ \\
\hline Milvago chimachima & 10 & 3 & $1 / 8$ & $0 / 2$ & $0 / 5$ & $0 / 6$ & $0 / 3$ \\
\hline Rupornis magnirostris & 26 & 17 & $1 / 12$ & $0 / 13$ & $0 / 5$ & $0 / 7$ & $0 / 14$ \\
\hline Strigiformes & 84 & & & & & & \\
\hline Athene cunicularia & 11 & 11 & $0 / 1$ & $5 / 6$ & $0 / 1$ & $0 / 1$ & $0 / 9$ \\
\hline Asio clamator & 23 & 13 & $6 / 13$ & $2 / 9$ & $0 / 11$ & $0 / 11$ & $0 / 12$ \\
\hline Asio stygius & 7 & 4 & $2 / 4$ & $0 / 4$ & $0 / 3$ & $0 / 4$ & $0 / 4$ \\
\hline Bubo virginianus & 2 & 2 & $0 / 1$ & $0 / 1$ & $0 / 1$ & $0 / 1$ & $0 / 1$ \\
\hline Glaucidium brasilianum & 6 & 6 & $0 / 0$ & $0 / 4$ & $0 / 6$ & $0 / 6$ & $0 / 5$ \\
\hline Megascops choliba & 6 & 6 & $0 / 0$ & $0 / 4$ & $0 / 6$ & $0 / 6$ & $0 / 4$ \\
\hline Strix huhula & 1 & 0 & $0 / 1$ & $0 / 1$ & $0 / 1$ & $0 / 1$ & $0 / 1$ \\
\hline Strix virgata & 1 & 0 & $0 / 1$ & $0 / 1$ & $0 / 1$ & $0 / 1$ & $0 / 1$ \\
\hline Tyto alba & 27 & 15 & $0 / 15$ & $0 / 13$ & $0 / 27$ & $0 / 11$ & $0 / 14$ \\
\hline Cathartiformes & 14 & & & & & & \\
\hline Coragyps atratus & 14 & 10 & $0 / 9$ & $0 / 8$ & $1 / 9^{6}$ & $0 / 9$ & $0 / 9$ \\
\hline
\end{tabular}

Notes. 'Peripheral blood smear (Giemsa) results for hemoparasites / total; ${ }^{2}$ Spleen PCR for Haemoproteus spp. - Plasmodium spp. /tested; ${ }^{3}$ Serum agglutination for Mycoplasma gallisepticum results/ tested; ${ }^{4}$ Haemagglutination-inhibition for antibodies to Newcastle disease virus; ${ }^{5}$ Liver PCR for Chlamydophila psittaci; ${ }^{6}$ Coragyps atratus retested by HI (negative). 
Andery D de A, Ferreira Junior FC, Araújo AV de, Vilela DA da $R$,

Marques MVR, Marin SY, Horta RS,

Ortiz MC, Resende JS de, Martins NR da S
Health Assessment of Raptors in Triage in Belo Horizonte, Mg, Brazil were submitted both to clinical examination and necropsy.

Organ (liver and spleen) fragments were frozen for PCR investigation or fixed in 10\% formalin for histological analysis. Intestinal content and mucosa scraping were examined under light microscopy (100 and 400x).

\section{Parasites}

Ectoparasites and feathers were collected in alcohol $70^{\circ} \mathrm{C}$ for microscopy. Endoparasites were fixed in 10\% formalin for subsequent identification. Sarcocystis sp. oocysts were cleared by centrifugation (10min/3000xg) in saturated $\mathrm{NaCl}$ solution, counted and $1,000 / 50 \mu \mathrm{L}$ resuspended in sterile PBS and intraperitoneally inoculated into Balb/c mice. Feces or intestinal contents containing oocysts were placed in potassium dichromate $2.5 \%$ for sporulation. Oocysts were characterized by their internal structures and morphometrics by microscopy (400x).

\section{Blood samples}

Birds were submitted to physical restriction in order to collect blood samples ( 0.5 to $1 \%$ of body weight) by ulnar or brachial venipuncture, with sterile disposable syringes and needles. Collected blood was used to prepare blood smears and for serum separation.

\section{Serology}

Fresh sera (not frozen) were individually tested by serum agglutination test (SAT) for antibodies against Mycoplasma gallisepticum (Mg) using a commercial kit (MYCO-TEST GALLI-Biovet $\AA$ ). Tests were performed according to PNSA (Brazil, 2001) and the manufacturer's recommendations, with equal parts of fresh serum and antigen $(50 \mu \mathrm{L})$. Known $\mathrm{Mg}$ positive and negative sera were used as controls.

Hemagglutination-inhibition ( $\mathrm{HI}$ ) test for Newcastle disease virus (APMV-1) antibodies was performed according to PNSA (Brazil, 2002), using La Sota strain of APMV-1 (New Vacin La Sota-Biovet $囚$ ) as antigen (inactivated by $\beta$-propiolactone), fresh adult SPF chicken red blood cells (RBC) suspension (1\%), and microtiter 96-well "u-bottomed" plates. Reference APMV-1 positive and negative sera were included in all tests, and retrotitration of the antigen to confirm 4 UHA. Two replicates were used for all tests, including controls. Serum titer was the reciprocal of the highest dilution showing complete RBC deposition, similar to normal RBC control wells.

\section{DNA Extraction and Quantification}

Silicon dioxide adsorption DNA extraction was previously described (Boom et al., 1990) and modified by Caxito et al. (2006), by protein denaturation using sodium iodide. Briefly, about $200 \mathrm{mg}$ (or $200 \mu \mathrm{L}$ ) of previously homogenized (liver orand spleen fragments) were added with three volumes $(600 \mu \mathrm{L})$ of sodium iodide (Nal, Labsynth, Brazil) and 50 $\mu$ l of a suspension of silica (Sigma-Aldrich Co., USA). The pellet was washed three times with a buffer $(50 \%$ ethanol, $50 \mathrm{mM}$ Tris$\mathrm{HCl}$ pH8.0, 10mM EDTA pH8.0) and once with acetone $\left(-4^{\circ} \mathrm{C}\right)$. DNA adhered to the silica (pellet) was eluted by adding $60 \mu \mathrm{l}$ of TE buffer $(10 \mathrm{mM}$ Tris- $\mathrm{HCl}$ pH8.0, $1 \mathrm{mM}$ EDTA pH8.0), and was then incubated $\left(50^{\circ} \mathrm{C}, 10 \mathrm{~min}\right)$ and centrifuged ( $2 \mathrm{~min}, 14000 \mathrm{rpm})$. The supernatant (template DNA) was removed and transferred into a fresh microtube and stored at $-20^{\circ} \mathrm{C}$ until use. The extracted DNA samples were analyzed and quantified $(\mathrm{ng} / \mu \mathrm{L}$ ) by a spectrophotometer (NanoDrop ND-1000, Thermo Fisher Scientific Inc., USA).

\section{Hemoparasites}

Hemoparasites were investigated in peripheral blood smears of 89 birds (45 Falconiformes, 35 Strigiformes and nine (athartiformes) and by PCR of 82 birds (33 Falconiformes, 41 Strigiformes and 8 Cathartiformes). Two smears were prepared per bird with freshly collected blood, immediately dried in air, fixed in methanol, and stained with Giemsa (Valkiünas, 2005). Two hundred microscopic fields were analyzed by immersion light microscopy $(1000 \mathrm{X})$ for the presence of hemoparasites.

PCR for Haemoproteus spp. and Plasmodium spp. was performed in spleen samples. DNA was extracted as described above, and PCR reactions were performed in a thermocycler (Maxygene, Axygen, USA) as previously described (Fallon et al., 2003), using the primers 343F-5'GCTCACGCATCGCTTCT-3' and 496R-5'GACCGGTCATTTTCTTTG-3'. In the amplification reaction, $2 \mu \mathrm{L}$ of DNA template and $13 \mu \mathrm{L}$ of the reaction buffer $(10 \mathrm{mM}$ Tris- $\mathrm{HCl}$, pH8.5, $50 \mathrm{mM}$

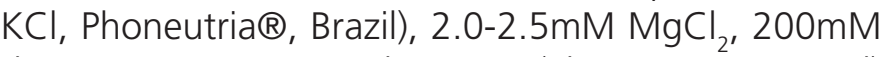
dNTP, 0.5U Taq DNA polymerase (Phoneutria $\AA_{\text {; }}$ Brazil) $0.4 \mathrm{mM}$ of each primer and sterile ultrapure water qsp) were used for 35 cycles of denaturation $\left(94^{\circ} \mathrm{C}, 1 \mathrm{~min}\right)$, annealing at $62^{\circ} \mathrm{C}$ for $1 \mathrm{~min}$ and extension at $72^{\circ} \mathrm{C}$ for $70 \mathrm{~s}$. The initial denaturation was performed at $94^{\circ} \mathrm{C}$ for $2 \mathrm{~min}$ and a final extension at $72^{\circ} \mathrm{C}$ for $3 \mathrm{~min}$. A final product with 192 base pairs was visualized by electrophoresis on non-denaturing $6 \%$ polyacrylamide 
gel in 1X TBE buffer, fixed in ethyl alcohol solution at $10 \%$ and $0.5 \%$ acetic acid, stained with silver nitrate solution, and fragments of DNA as evidenced in a developing solution of sodium hydroxide and formaldehyde (Sanguinetti et al., 1994). Genomic DNA of Plasmodium gallinaceum was used as positive control and SPF-chicken DNA sample extracted from the blood was used as negative control.

\section{PCR for Chlamydophila psittaci}

Chlamydophila psittaci (Cp) DNA was investigated in liversamplesbyPCR(Sachseetal., 2009), using theprimers Cp-F-5'-ACTACGGAGATTATGTTTTCGATCGTGT-3' and Cp-R-3'TCTTGGAGCGTYGGTGCACG-5'. In the amplification reaction, 200ng of template DNA, $2 \mu \mathrm{L}$ of $10 \mathrm{X}$ buffer $(200 \mathrm{mM}$ Tris- $\mathrm{HCl}$ pH8.4, 500mM KCl), $1 \mu \mathrm{L}$ of $10 \mathrm{mM}$ dNTP, $1 \mu \mathrm{L} 50 \mathrm{mM} \mathrm{MgCl}{ }_{2}, 1 \mu \mathrm{L}$ of each primer, $0.1 \mu \mathrm{L}$ of Taq Polymerase $5 \mathrm{U} / 1 \mu \mathrm{L}$ (Platinum Taq DNA Polymerase) and ultra pure water qsp were used to a final volume of $20 \mu$ l. All reagents were supplied by Invitrogen $®$ (USA). Reactions were performed in a thermocycler (Maxygene, Axygen, USA), with an initial denaturation cycle of $96^{\circ} \mathrm{C}$ for $60 \mathrm{~s}$, followed by 40 denaturation cycles at $94^{\circ} \mathrm{C}$ for $30 \mathrm{~s}$, annealing at $50^{\circ} \mathrm{C}$ for $60 \mathrm{~s}$, and extension at $72^{\circ} \mathrm{C}$ for 30 s, plus a final extension at $72^{\circ} \mathrm{C}$ for $4 \mathrm{~min}$, yielding a final product of $418 \mathrm{bp}$. DNA extracted from the liver of a bird diagnosed with $C p$, as confirmed in other laboratories, was employed as positive control. The DNA extracted from liver of SPF chickens was used as negative control. PCR products were resolved by electrophoresis on $1 \%$ agarose gel, stained by ethidium bromide (10 mg/ $\mathrm{mL}$ ) and visualized under UV transiluminator (Hoefer Scientific Instruments, USA).

\section{RESULTS}

\section{Birds}

The raptor species evaluated in the present study are shown in Table 1. Out of Cathartiformes, only Coragyps atratus was evaluated $(n=14)$. The following were evaluated. Considering Falconiformes $(n=82)$, Caracara plancus and Rupornis magnirostris $(\mathrm{n}=26)$, representing $63.4 \%$, Milvago chimachima $(12.1 \%, \mathrm{n}=10)$ and Falco sparverius ( $n=8,9.9 \%$ ), both representing $85.4 \%$ of the total, were studied. Out of the Strigiformes $(n=84)$, Tyto alba (32.1\%, $\mathrm{n}=27)$, Asio clamator $(27.3 \%$, $\mathrm{n}=23)$, Athene cunicularia (13.0\%, $\mathrm{n}=11)$, Asio stygius $(8.3 \%, \mathrm{n}=7)$, Glaucidium brasilianum $(7.1 \%, \mathrm{n}=6)$ and Megascops choliba $(7.1 \%, \mathrm{n}=6)$, representing 95.8\% of owls, were examined.

\section{Necropsy}

Out of the 109 birds necropsied, 42 were Falconiformes, 57 Strigiformes and 10 Cathartiformes. Absolute number of deaths among Strigiformes was greater than the sum of the deaths in the other groups, which were $72 \%, 68 \%$, 51\% for Cathartiformes, Strigiformes and Falconiformes, respectively. Most birds died during triage. However, four owls and one C. atratus died immediately after being rescued. Eight Falconiformes, four Strigiformes and seven Cathartiformes were rescued and euthanized due to post-traumatic suffering. Ten percent of the dead birds were young and $90 \%$ were adults; $46.8 \%$ were males and $39.4 \%$ females; however, age and sex were not determined in $13.7 \%$ due to advanced autolysis of their bodies.

Trauma was the main cause of rescue of raptors at CETAS, affecting 63.3\% (69/109) of birds necropsied, and according to taxonomic order, $66.7 \%$ (28/42) Falconiformes, $56.1 \%$ (32/57) Strigiformes, and $90 \%$ (9/10) Cathartiformes. Conditions included electrocution, fracture and traumatic amputation of extremities, traumatic brain injury (TBI), projectile injury, kite line or barbed wire cuts/amputation, fall from the nest and other undetermined causes. In 18.8\% (13/69) of cases, it was not possible to determine the cause of the injury.

At necropsy, 38.5\% (42/109) of the birds presented fractures, or $60.9 \%$ (42/69), of birds with trauma. According to taxonomic order, 42.9\% (18/42) Falconiformes, 36.8\% (21/57) Strigiformes, and 30\% (3/10) of Cathartiformes presented fractures. Relative to fracture site, $57.1 \%(24 / 42)$ were located in the thoracic limbs, $14.3 \%(6 / 42)$ in the pelvic limbs, $11.9 \%$ (5/42) had multiple fractures, and $16.7 \%$ (7/42) in pelvic bones, beak, rib and skull.

Two birds suffered fatal electrocution (2/69): an $A$. stygius with foot burns, and an C. atratus, with about $50 \%$ of its body surface burnt. Traumatic amputation $(3 / 69)$ of the extremities were observed at the metatarsus (C. atratus), and tarsus and $3^{\text {rd }}$ finger ( $R$. magnirostris). Cases of TBI were observed in four birds with traumatic conditions, including $R$. magnirostris, $A$. cunicularia, Megascops choliba, and A. clamator, with history of neurological signs. One case (A. cunicularia) of skull fracture was detected. Injuries caused by firearm (2/69) were observed in $R$. magnirostris and Buteo brachyurus by finding the projectile in the lesions, which included humerus fracture, skin and intercostal muscle perforation, rib fracture with ruptured lung, 
and extensive pulmonary hemorrhage. Injuries caused by kite line (3/69) included two C. plancus and one $A$. clamator presenting skin, muscle and tendon laceration, and tissue loss in the forelimbs. One A. clamator had the right forelimb tangled in barbed wire. There were three cases of feathers covered with an oily chemical (3/109): one Athene cunicularia, one T. alba, and one F. sparverius. Cachexia was observed in 11 birds (11/109) with pectoral muscle atrophy, being nine Strigiformes and two Falconiformes, although not observed in Cathartiformes. The young birds that fell from the nest (3/69) included two C. plancus, one of which at hatch, and one C. atratus. Ophthalmic lesions (4/109) included corneal ulcer and opacity, exsudate, lens dislocation, hyphema, and exophthalmia. One bird had suppurative ocular injury associated with trichomoniasis at an advanced stage. Respiratory mycotic granulomas were observed in three Strigiformes, one Falconiformes and three Cathartiformes (7/109).

\section{Parasites}

Endoparasites (Table 2) were observed in 11\% $(12 / 109)$ of the necropsied birds, being $11.9 \%$ (5/42) Falconiformes and $12.3 \%$ (7/57) Strigiformes, but none in Cathartiformes. In some cases, the same bird showed parasitism by more than one species of helminths. Nematodes were found in $12.8 \%$ (14/109) of birds, cestodes in $1.8 \%$ (2/109), trematodes in $0.9 \%(1 / 109)$ and acanthocephalans in 2.7\% (3/109). Endoparasitism by helminths in the air sacs were found in three $T$. alba, and were preliminarily identified as Hamatospiculum sp. A high parasite load of acanthocephalans fixed to the small intestine mucosa was found in one Leptodon cayanensis.

Coccidiosis, Histomonas spp. and Trichomonas spp. were the protozoan infections found. Coccidiosis was detected in $9.1 \%(10 / 109)$ of birds, Histomonas spp. in $6.4 \%$ (7/109) and Trichomonas spp. in 9.1\% (10/109). Among Trichomonas spp. infections, 50\% of cases were found in Falconiformes and 50\% in Strigiformes, including $R$. magnirostris, M. chimachima, F. femoralis, F. sparverius, C. plancus, A. cunicularia, A. clamator, G. brasilianum, and T. alba. No case of trichomoniasis was observed in Cathartiformes. Diphteritic plaque lesions were observed in all Trichomonas infection cases in the oral cavity, and in some cases, involving the oropharynx, nasal cavity and infraorbital sinuses. All birds diagnosed with trichomoniasis died. The cases of Histomonas spp. were characterized by the observation of motile cells in cecal and cloacal lumen, in $12 \%$ Strigiformes of the species B. virginianus,
Table 2 - Endoparasites found in raptor birds rescued or at the triage center of CETAS-Belo Horizonte, Brazil between 2008-2010.

\begin{tabular}{lll}
\hline Parasite & Raptor bird host & Tissue location \\
\hline Nematode & & \\
Ascaridia sp. & Rupornis magnirostris & Small intestine \\
\hline Filarid & Asio stygius & Cloaca \\
Hamatospiculum sp. & Tyto alba & Air sac \\
Hamatospiculum sp. & Tyto alba & Air sac \\
Hamatospiculum sp. & Tyto alba & Air sac \\
Physaloptera acuticauda & Leptodon cayanensis & Esophagus \\
Porrocaecum sp. & Rupornis magnirostris & Small intestine \\
\hline Procyrnea mansioni & Rupornis magnirostris & Gizzard \\
Spirurídeo (Subfamily & Asio stygius & Esophagus \\
Spirurinae) & Tyto alba & Gizzard \\
Streptocara pectinifera & Athene cunicularia & Proventriculus \\
Tetrameres sp. & Asio stygius & Proventriculus \\
Tetrameres sp. & Asio stygius & Proventriculus \\
Tetrameres sp. & Leptodon cayanensis & Proventriculus \\
Tetrameres sp. & &
\end{tabular}

Cestode

$\begin{array}{lll}\text { Cestoda } & \text { Asio clamator } & \text { Small intestine } \\ \text { Cestoda } & \text { Rupornis magnirostris } & \text { Duodenum }\end{array}$

Trematode

Trematoda
(Diplostomatidae) Rupornis magnirostris Small intestine

Acantocephala

Acanthocephala

Acanthocephala

Centrorynchus sp.

Leptodon cayanensis Small intestine

Asio clamator Small intestine

Leptodon cayanensis Jejunum

A. cunicularia T. alba and A. clamator, but none in Falconiformes or Cathartiformes. Heterakis gallinarum, an intermediate host of the parasite in chicken, was not detected.

Three T. alba were parasitized by more than one protozoan, being two by Sarcocystis spp. and Histomonas spp., and one in addition to the previous two, also by T. gallinae. Despite the low occurrence, trichomoniasis was an apparently major cause of death in Falconiformes and Strigiformes. Sarcocystis spp. was observed in $77 \%$ (7/9) T. alba with coccidiosis, the only species affected.

Ninety percent of coccidiosis cases occurred in owls and $10 \%$ in Coragyps atratus, with no case in Falconiformes. Oocyst sporulation did not occur in two cases of $A$. cunicularia. Sarcocystis spp. were found sporulated in the feces of $T$. alba. Oocysts contained 
Andery D de A, Ferreira Junior FC, Araújo AV de, Vilela DA da R, Marques MVR, Marin SY, Horta RS, Ortiz MC, Resende JS de, Martins NR da S two sporocysts surrounded by a thin membrane, giving an appearance of paired-oocysts. Sarcocystis oocysts $(n=130)$ measured $19.41 \mu \mathrm{m} \pm 1.14 \mu \mathrm{m} x$ $12.17 \mu \mathrm{m} \pm 0.97 \mu \mathrm{m}$ and measurements of sporocysts were $12.17 \mu \mathrm{m} \pm 0.97 \mu \mathrm{m} \times 9.98 \mu \mathrm{m} \pm 0.58 \mu \mathrm{m}$. Diffuse residues were present within the sporocysts. Inoculated sporulated Sarcocystis sp. given intraperitoneally to Balb/c mice and incubated for 60 days, did not result in muscular lesions.

At necropsy, 9.2\% (10/109) of birds (two Strigiformes, one Cathartiformes and seven Falconiformes) were parasitized by hippoboscid, 17.4\% (19/109) by mites (sixteen Strigiformes, two Falconiformes and one Cathartiformes) and $10.1 \%(11 / 109)$ by chewing lice (one Strigiformes, six Cathartiformes and four Falconiformes).

Ornithonyssus sylviarum (Macronyssidae) caused clinical change in one $A$. clamator that died with a low hematocrit (17\%), with intense pericloacal parasitism with skin crusting. Parasitism by Amblyomma spp. was observed attached close to the ear in one T. alba.

\section{Serology}

\section{SAT for Mg}

Sixty-five sera were analyzed (28 Falconiformes, 28 Strigiformes and nine Cathartiformes) for the presence of anti-Mg antibodies all proven negative. In one $C$. atratus a nonspecific SAT reactivity was detected, although shown negative by $\mathrm{HI}$ (Table 1).

\section{HI for APMV-1 antibodies}

Sera of 68 birds (30 Falconiformes, 29 Strigiformes and nine (athartiformes) were tested for anti-APMV-1 antibodies. Only two C. plancus had titers (16 and 32), representing $15.4 \%(2 / 13)$ of the species and $6.7 \%$ (2/30) of the order (Table 1).

\section{Hemoparasites}

A general parasitism rate of $13.5 \%(12 / 89)$ was observed in the peripheral blood and $8.5 \%(7 / 82)$ in the spleen (Table 1). Hemoparasitism in Falconiformes was $8.9 \%$ (4/45), all determined in blood smears and none by PCR. In Strigiformes, blood smears were $22.8 \%$ (8/35) positive, but only $17.1 \%$ (7/41) were positive by PCR. No Cathartiformes showed hemoparasites. The morphology of the hemoparasites was consistent with genus Haemoproteus.

Fourteen birds were analyzed for hemoparasitism both by PCR and blood smear, and eight were negative
Health Assessment of Raptors in Triage in Belo Horizonte, Mg, Brazil

in both tests, one was positive by both techniques, four were PCR negative but positive by blood smear (low parasitism), and one was positive only by PCR (Table 1).

Three birds ( $B$. brachiurus, $A$. stygius and $R$. magnirostris) were positive (3/10) for Haemoproteus spp., and hippoboscid louse-flies (Hippoboscidae) were found. A sample of louse-fly was collected on B. brachiurus and submitted to PCR. DNA extraction (silica) was performed separately on the head and abdomen of the vector and Haemoproteus spp. specific DNA was found in both sections.

\section{Chlamydophila psittaci}

Ninety five liver samples (37 Falconiformes, 49 Strigiformes and 9 (athartiformes) were tested negative for C. psittaci by PCR.

\section{DISCUSSION}

The number of individuals evaluated indicated that the populations of raptors suffer significant and varied health pressures when inhabiting the periurban environment. Joppert (2007) studied 114 raptors in São Paulo for 3.5 years, and most (65\%) were Strigiformes, in agreement with our findings. Komnenou et al. (2005), in a 3-year retrospective study in Greece, registered only $18 \%$ owls among 402 raptors evaluated. Environmental, behavioral or ecological factors may explain these differences in incidence of taxonomic groups. The twenty studied species constitute approximately $21 \%$ of the total taxa recorded for the group in Brazil, being 15\%, 39\% and 17\% Falconiformes, Strigiformes and Cathartiformes, respectively. However, the species $T$. alba, A. clamator, $R$. magnirostris and C. plancus represented more than half $(57 \%)$ of birds studied, possibly because of their greater population in urban environments. Sick (1997) classified these taxa as generalists, capable of establishing populations in urban and peri-urban environments.

Trauma findings were in agreement with previous reports on raptors (Komnenou et al., 2005), which described trauma as the most important cause of morbidity. Urban Falconiformes were mostly affected by vehicle collisions and electrocutions, while vehicular and window strikes are the most common causes of trauma in urban Strigiformes (Hager, 2009). Fractures were the single most important cause of morbidity, in agreement with previous reports (Naldo and Samour, 2004). According to Arnaut (2006), fractures of 
Andery D de A, Ferreira Junior FC Araújo AV de, Vilela DA da R,

Marques MVR, Marin SY, Horta RS,

Ortiz MC, Resende JS de, Martins NR da S

thoracic or pelvic limbs are the most common, which is consistent with our findings. Cachexia was observed in Strigiformes and Falconiformes. Cathartiformes are mostly scavengers and do not need to hunt, searching for food in city waste.

The observed helminthic infection rates were lower than those previously reported by Joppert (2007), of $25.4 \%$, and by Santoro et al. (2010), of 95\%. The impact of those infections is generally considered low, except when associated with other diseases and stress. Hamatospiculum sp. was incidentally found in Tyto alba air sacs. On the other hand, an intense infection by an acanthocephalan was found in the small intestine mucosa of Leptodon cayanensis, and it is possibly associated with the bird's death. Acanthocephalans were previously described in Falconiformes and Strigiformes (Sanmartin et al., 2004). The other endoparasites found (Table 2) are consistent with literature reports (Gomez et al., 1993; Smith, 1996; Krone and Cooper, 2002; Fagerholm and Overstreet, 2008; Honisch and Krone, 2008; Kinsella and Forrester, 2008; Santoro et al., 2011).

Hippoboscid flies, Ornithonyssus sylviarum, ticks and chewing lice were previously described in raptors (Philips, 2000) and were found in all Orders evaluated in the present study. These parasites may be associated with chickens, pigeons and sparrows (Arends, 2003). During rehabilitation, the proximity of raptors with free-living pigeons, sparrows, and other species, including reptiles and mammals, may allow their infection by ectoparasites. Mites had a negative effect on hematocrit values, which were below the $36 \%$ normally reported for Asio clamator (Sanchez et al., 2005).

Trichomoniasis may have contributed for the morbidity and mortality of raptors (Forrester and Foster, 2008), and accounted in the present study for half of the protozoan occurrences in Falconiformes and Strigiformes. Pigeons have been diagnosed with trichomoniasis in the region (Resende et al., 2001) and may have contributed as sources of infection. Higher morbidity and mortality associated with greater pigeon population was reported in urban raptors compared with rural ones (Boal et al., 1998). Histomoniasis occurs in poultry of the region (unpublished data), and in the present study, Histomonas meleagridis (common in Phasianidae) affected only Strigiformes, and no Heterakis gallinarum, considered an intermediate host, was found in the infected owls, as previously described in Buteo buteo (Özmen et al., 2009).

\section{Health Assessment of Raptors in Triage in Belo Horizonte, Mg, Brazil}

Coccidiosis occurred mostly in Strigiformes, and also in Cathartiformes, but not in Falconiformes. Sporulated oocysts of Sarcocystis spp. (Krone, 2007) were characterized by morphometry in Tyto alba. Measurements were similar to Isospora buteonis (Mathey, 1966), reclassified as Sarcocystis spp. (Lindsay and Blagburn, 1989; Modry et al., 2004). However, Sarcocystis dispersa is considered specific of $T$. alba (Dolezel et al., 1999). Tyto alba is also known for protozoan (Sarcocystis spp. and Histomonas spp.) coinfections. Sarcocystis sp. in Buteo borealis was not associated with clinical disease (Lindsay et al., 1987), but in Falco sparverius, it was associated with mortality (Mathey, 1966). Sinantropic rodents may be source of infection for T. alba (Rommel and Krampitz, 1975). However, no lesions were detected in inoculated mice, suggesting important biological differences (Munday, 1977).

Serology for Mg was negative. Raptors in the triage center are kept for a short time in captivity, and those birds that able to fly are released after support therapy, while birds with irreversible trauma are euthanized. Transmission during triage may be low if compared with other bird classes, such as Psittaciformes or Passeriformes, which may remain longer in the center, thereby increasing the risk of cross-infections. In Brazil, PCR detection of $\mathrm{Mg}$ revealed that $51.9 \%$ of the dead Psittaciformes tested in a triage center (CETAS-BH) were positive (Gomes et al., 2010), suggesting that large populations, common housing of birds of different origins and history of proximity with free-range poultry, could account for high levels of infection.

The studied raptors in Minas Gerais may not pose risks for commercial poultry, at least considering $M$. gallisepticum. However, several species of Mycoplasma were previously described in raptors (Panangala et al., 1993; Poveda et al., 1994; Oaks et al., 2004; Lierz et al., 2008a; Lierz et al., 2008b; Loria et al., 2008; Ruder et al., 2009). Species considered pathogenic for commercial poultry were occasionally reported in raptors (Lierz et al., 2008a). Distance and biosecurity are essential both for wild bird centers and poultry production sites, and there must be regular surveillance, as the infection may occur in both directions (Farmer et al., 2005).

Our findings for antibodies against APMV-1 were consistent to those previously described (Schettler et al., 2001). Low, but significant, titers were only found in C. plancus, which is commonly found close to human activity, including garbage dumps and poultry farms. Chickens usually receive live APMV-1 vaccines and 
vaccine strain infection of free-living neighboring birds may be possible. Schettler et al. (2003) described a La Sota (vaccine-type) APMV-1 strain in T. alba. This strain is the most commonly used in Brazil for the protection of chicken flocks. The widespread use of live APMV-1 vaccines for poultry may render the correct evaluation of APMV-1 natural circulation difficult (Aldous and Alexander, 2001). Raptors fed with farm residues or living close to chickens presented a high level of infection (Chu et al., 1976). Lentogenic APMV-1 was also detected in Haliaetus leucocephalus and Bubo virginianus, but not in Accipiter cooperi, Carthartes aura and C. atratus (Jindal et al., 2010). Although most APMV-1 strains endemic in wild birds are lentogenic, deficient biosecurity in poultry facilities may enable challenge with virulent strains (Camenisch et al., 2008). The raptors in this study may not pose risks to commercial poultry regarding APMV-1.

No hemoparasitism clinical signs were observed in the evaluated raptors and the incidence of Haemoproteus spp. was consistent with previous findings in raptors (Krone et al., 2001; Andery et al., 2010). The association of hippoboscid louse-flies and Haemoproteus (Remple, 2004) was here also observed. The triage center attracted free-living pigeons with hippoboscids, which were also found in positive raptors. Haemoproteus spp. DNA was found in both portions of the fly, possibly indicating vector infection. It was described that this agent replicates in the gut and migrate to the salivary glands of flies (Friend and Franson, 1999). Results of birds tested both by blood smears microscopy and spleen PCR lacked agreement. Conflicting results have also been described (Krone et al., 2008), although PCR is considered more sensitive (Hellgren et al., 2004). False negative results by PCR may result from genetic variation or low parasitemia (Fallon et al., 2003).

Although Cp DNA was not detected in raptor livers, these results may not represent the actual status. Falsenegative results were described and were attributed to the intermittent nature of the infection (Andersen and Vanrompay, 2003). In São Paulo, Cp-specific antibodies were detected in $16 \%$ of the raptors in the Zoological Garden, but no C $p$ was detected by PCR of cloacal swabs (Raso et al., 2005). However, birds may be negative for antibodies but present positive $P C R$ in recent infections (Raso et al., 2006). Cp detection was reported by Schettler et al. (2001), who studied lung and spleen by PCR and obtained 74\% positivity, suggesting that raptors may play a role in the epidemiology of this disease.
Among the several anthropic-related affections, trauma represented the main cause for submission to triage and death. The urban adaptation of wild avian species, as a consequence of habitat loss and behavioral change, poses new challenges for the wild fauna. A new perception for the harmonious coexistence is needed for the preservation of these animals.

\section{ACKNOWLEDGEMENTS}

The authors are indebted to CAPES, CNPq, FAPEMIG and FEP/MVZ for funding and to IBAMA and ICMBio for providing the birds. We are grateful to Gabriel M. Félix and Prof. Érika M. Braga for technical advice on malaria and Lucas Maciel Cunha and Prof. Alan L. de Melo for the identification of parasites. This project is part of the National Institute of Science and Technology, Genetic and Health Information of the Brazilian Livestock [Instituto Nacional de Ciência e Tecnologia (INCT) - Informação Genético-Sanitária da Pecuária Brasileira (IGSPB)].

\section{REFERENCES}

Aldous EW, Alexander DJ. Detection and differentiation of Newcastle disease virus (avian paramyxovirus type 1). Avian Pathology 2001,30:117-128.

Andersen AA, Vanrompay D. Avian chlamydiosis (psittacosis, ornithosis). In: Saif YM, editor. Diseases of poultry. 11nd ed. lowa: State Press; 2003. p. 719-721.

Andery DA, Horta RS, Ferreira Junior FC, Araújo AV, Marques MVR, Vilela DAR, Resende JS, Martins NRS. Ocorrência de hemoparasitos em Falconiformes, Strigiformes e Cathartiformes recebidos pelo Centro de Triagem de Animais Silvestres (CETAS) do IBAMA de Belo Horizonte/ MG no ano de 2009. Anais do Congresso ABRAVAS; 2010; Campos do Jordão, São Paulo. Brasil;2010. p. 50

Arends JJ. External parasites and poultry pests. In: Saif YM, editor. Diseases of poultry. 11nd ed. lowa: lowa State Press; 2003. p. 905-930.

Arnaut LS. Estudo radiográfico das afecções do sistema esquelético em aves. [dissertation]. São Paulo (SP): Universidade de São Paulo; 2006. $121 \mathrm{p}$.

Boal CW, Mannan RW, Hudelson KS. Trichomoniasis in Cooper's Hawks from Arizona. Journal of Wildlife Diseases 1998;34:590-593.

Boom R, Sol CJ, Salimans MM, Jansen CL, Wertheim-van Dillen PM, Noordaa J van der. Rapid and simple method for purification of nucleic acids. Journal of Clinical Microbiology 1990,28:495-503.

Brasil. Instrução Normativa SDA Nº. 32, de 13 de maio de 2002. Anexo Normas Técnicas de Vigilância para Doença de Newcastle e Influenza Aviária, e de controle e erradicação para a doença de Newcastle. Diário Oficial da União 2002 Maio 14; Seção 1. 14p.

BrASIL. Instrução Normativa SDA No. 44, de 23 de agosto de 2001 Anexo Normas Técnicas para o Controle e a certificação de núcleos e estabelecimentos avícolas para a micoplasmose aviária (Mycoplasma gallisepticum, M. synoviae e M. meleagridis). Diário Oficial da União 2001 Ago 24; Seção1. 10p. 
Camenisch G, BAndLI R, Hoop R. Monitoring of Wild birds for Newcastle Disease Virus in Switzerland Using Real Time RT-PCR. Journal of Wildlife Diseases 2008,44:772-776.

Caxito FA, Coelho FM, Oliveira ME, Resende M. Feline immunodeficiency virus subtype B in domestic cats in Minas Gerais, Brazil. Veterinary Research Communications 2006; 30:953-956.

Chu HP, E.W. Trow EW, Greenwood AG, Jennings AR, Keymer IF. Isolation of Newcastle disease virus from birds of prey. Avian Pathology $1976,5: 227-233$

Dolezel D, Koudelaa B, Jirkuê M. Phylogenetic analysis of Sarcocystis spp. of mammals and reptiles supports the coevolution of Sarcocystis spp. With their final hosts. International Journal for Parasitology 1999;29:795798.

Fagerholm HP, Overstreet RM. Ascaridoid Nematodes: Contracaecum, Porrocaecum, and Baylisascaris. In: Atkinson CT, Thomas NJ, Hunter DB. Parasitic diseases of wild birds. Iowa: Wiley-Blackwell; 2008. p. 420-440.

Fallon SM, Ricklefs RE, Swanson BL, Bermingham E. Detecting avian malaria: an improved polymerase chain reaction diagnostic. Journal of Parasitology 2003,89:1044-1047.

Farmer KL, HiLl GE, Roberts SR. Susceptibility of wild songbirds to the house finch strain of Mycoplasma gallisepticum. Journal of Wildlife Diseases 2005;41:317-325.

Forrester DJ, Foster GW. Trichomonosis. In: Atkinson CT, Thomas NJ, Hunter DB. Parasitic diseases of wild birds. lowa: Wiley-Blackwell; 2008. p.120-153

Friend M, Franson J. Field manual of wildlife diseases: general field procedures and diseases of birds. Madison: National Wildlife Health Center,; 1999, 440 p. Available from: http://www.nwhc.usgs.gov/ publications/ field_manual/.

Gomes AM, Costa LL, Vilela DAR, Marques MVR, Carvalhaes AG, Marin SY, Costa MP, Horta RS, Resende JSMartins NRS. Detection of Mycoplasma gallisepticum in Dead Captive Psittacines in Belo Horizonte, Brazil. Brazilian Journal of Poultry Science 2010,12:101-104.

Gomez LPI, Osorio MR, Maza FA. Parasitation of falconiform, strigiform and passeriform (Corvidae) Birds by Helminths in Spain. Research and Reviews in Parasitology 1993;53: 129-135.

Hager SB. Human-related threats to urban raptor. Journal Raptor Research 2009,43: 210-226

Hellgren O, Waldenström J, Bensch S. A new PCR assay for simultaneous studies of Leucocytozoon, Plasmodium, and Haemoproteus from avian blood. Journal of Parasitology 2004;90:797-802.

Höfle U, Blanco JM, Kaleta EF. Seroprevalence of avian paramyxovirus 1, 2 , and 3 in captive and free-living birds of prey in Spain (preliminary results): implications for management of wild and captive populations. Annals of the New York Academy of Sciences 2002;969:213-216.

Honisch M, Krone O. Phylogenetic relationships of Spiruromorpha from birds of prey based on 18S Rdna. Journal of Helminthology 2008;82:129-33.

ICMBı. Plano de ação nacional para a conservação de aves de rapina. Brasília: Instituto Chico Mendes de Conservação da Biodiversidade; 2008. $136 \mathrm{p}$

Jindal N, Chander Y, Primus A, Redig PT, Goyal SM. Isolation and molecular characterization of Newcastle disease viruses from raptors. Avian Pathology 2010;39: 441-445.

Joppert AM. Estudo prospectivo das causas de morte de Falconiformes e Strigiformes de vida livre no município de São Paulo [tese]. São Paulo
(SP): Faculdade de Medicina Veterinária e Zootecnia, Universidade de São Paulo; 2007. 238p

Kinsella JM, Forrester DJ. Tetrameridosis. In: Atkinson CT, Thomas NJ, Hunter DB, Parasitic diseases of wild birds. Iowa: Wiley-Blackwell; 2008. p.383-390.

Komnenou AT, Georgopoulou I, Savvas I, Dessiris A. A retrospective study of presentation, treatment, and outcome of free-ranging raptors in greece (1997-2000). Journal of Zoo and Wildlife Medicine 2005,36:222-228.

Krone O. Pathology. C. Endoparasites. In: Bird DM, Bildstein KL, editor. Raptor research and management techniques. Blaine, WA: Hancock House Publishers; 2007. p. 318-328.

Krone O, Cooper JE. Parasitic diseases. In: Cooper JE. Birds of prey: health and disease. Malden: Blackwell Science Inc, Malden; 2002 p. 105-120.

Krone O, Priemer J, Streich J, Sömmer P, Langgemach T Lessow 0. Haemosporida of birds of prey and owls from Germany. Acta Protozoologica 2001;40:281-289.

Krone O, Waldenström J, Valkiünas G, Lessow O, Müller K, lezhova TA, J. Fickel J, Bensch S. Haemosporidian blood parasites in European Birds of Prey and Olws. Journal of Parasitology 2008,94:709-715.

Lierz M, Hagen N, Hernadez-Divers SJ, Hafez HM. Occurrence of Mycoplasmas in Free-ranging Birds of Prey in German. Journal of Wildlife Diseases 2008a,44:845-850.

Lierz M, Hagen SJ, Lueschow D, Hafez HM. Use of polymerase chain reactions to detect Mycoplasma gallisepticum, Mycoplasma imitans, Mycoplasma iowae, Mycoplasma meleagridis and Mycoplasma synoviae in birds of prey. Avian Pathology 2008b;37:471-476.

Lindsay DS, Ambrus SI, Blagburn BL. Frenkelia sp.-like infection in the small intestine of a Red-tailed Hawk. Journal of Wildlife Diseases 1987;23:677-679

Lindsay DS, Blagburn BL. Caryospora uptoni and Frenkelia sp.-like coccidial infections in red-tailed hawks (Buteo borealis), Journal of Wildlife Diseases 1989;25:407-409.

Loria GR, Ferrantelli E, Giardina G, LI Vecchi L, Sparacino L, Oliveri F, McAuliffe L, Nicholas RA. Isolation and Characterization of Unusual Mycoplasma spp. From Captive Eurasian Griffon (Gyps fulvus) in Sicily. Journal of Wildlife Diseases 2008,44:159-163.

Mathey VJ. Isospora buteonis Henry 1932 in an American Kestrel (Falco sparverius) and a Golden Eagle (Aquila chrysaeto). Bulletin of Wildlife Disease Association 1966:2:20-22.

Matushima ER. Técnicas necroscópicas. In: Cubas ZS, Silva JCR, Catão-Dias JL. Tratado de animais selvagens - medicina veterinária. São Paulo: Roca; 2007. p. 980-990.

Modry D, Votypka J, Svobodov M. Note on the taxonomy of Frenkelia microti (Findlay \& Middleton, 1934) (Apicomplexa: Sarcocystidae). Systematic Parasitology 2004,58:185-187.

Munday BL. A species of Sarcocystis using owls as definitive hosts. Journal of Wildlife Diseases 1977,13:205-207.

Naldo JL, Samour JH. Radiographic findings in captive falcons in Saudi Arabia. Journal of Avian Medicine and Surgery 2004,18:242-256.

Oaks JL, Donahoe SL, Rurangirwa FR, Rideout BA, Gilbert M, Virani MZ. Identification of a novel Mycoplasma sspecies from an oriental WhiteBacked Vulture (Gyps bengalensis), Journal of Clinical Microbiology 2004,42:5909-5912

Özmen O, Haligür M, Adanir R. Identification of different protozoa species from a common buzzard (Buteo buteo). Turkish Journal of Veterinary and Animal Sciences 2009,33:257-260. 
Panangala VS, Stringfellow JS, Dybvig K, Woodard A, Sun F, Rose DL, Gresham MM. Mycoplasma corogypsi sp. nov., a new species from the Footpad abscess of a Black Vulture, Coragyps atratus. International Journal of Systematic Bacteriology 1993,43: 585-590.

Philips JR. A review and checklist of the parasitic mites (Acarina) of the falconiformes and strigiformes. Journal of Raptor Research $2000,34: 210-231$.

Poveda JB, Giebel J, Kirchhoff H, Fernandez A. Isolation of mycoplasmas from a buzzard, falcons and vultures. Avian Pathology 1990;19:779-783

Raso TF, Seixas GHF, Guedes NMR, Pinto AA. Chlamydophila psittaci in freeliving Blue-fronted Amazon parrots (Amazona aestiva) and Hyacinth macaws (Anodorhynchus hyacinthinus) in the Pantanal of Mato Grosso do Sul, Brazil. Veterinary Microbiology 2006,117:235-241.

Raso TF, Teixeira RHF, VAz FJ, Nogali O, Pinto AA. Pesquisa de Chlamydophila psittaci em ramphastídeos da Fundação Parque Zoológico de São Paulo. In: IX Congresso e XIV Encontro da ABRAVAS. 2005, São José do Rio Preto/sp, pp.78.

Remple JD. Intracellular hematozoa of raptors: a review and update. Journal of Avian Medicine and Surgery 2004;18:75-88.

Resende JS, Martins NRS, Jorge MA. An outbreak of malaria by Haemoproteus columbae in pigeons. Arquivo Brasileiro de Medicina Veterinária e Zootecnia 2001;53:361-363.

Rommel VM, E. Krampitz E. Beitäge zum Lebenszyklus den Frenkelien. I Die Identität von Isospora buteonis aus den Mäusebussard mit einer Frenkelienart (F. clethnionomyobuteonis spec n.) aus der Rötelmaus. Berlin München Tierärztl 1975;88: 338-340

Ruder MG, Feldman SH, Wünschmann A MCRUER DL. Association of Mycoplasma corogypsi and Polyarthritis in a black vulture (Coragyps atratus) in Virginia. Journal of Wildlife Diseases 2009,45:808-816.
Sachse K, Laroucau K Vorimore F Magnino S Feige J W, Müller W Kube S Hotzel H. Schubert E Slickers P, Ehricht R. DNA microarray-based genotyping of Chlamydophila psittaci strains from culture and clinical samples. Veterinary Microbiology 2009;135:22-30.

Sanguinetti CJ, Dias Neto E, Simpson AJG. Rapid silver staining and recovery of PCR products separated on polyacrylamide gels. Biotechniques $1994 ; 17: 915-919$

Sanmartín ML, Álvarez F, Barreiro G, Leiro J. Helminth fauna of falconiform and strigiform birds of prey in Galicia, Northwest Spain. Parasitology Research 2004; 92:255-263.

Santoro M, Tripepi M, Kinsella JM, Panebianco A, Mattiucci S. Helminth infestation in birds of prey (Accipitriformes and Falconiformes) in Southern Italy. The Veterinary Journal 2010;186:119-122.

Santoro M, Kinsella JM, Galiero G, Uberti B, Aznar FJ. Helminth community structure in birds of prey (Accipitriformes and Falconiformes) in Southern Italy. Journal of Parasitology 2011,98(1):22-29).

Schettler E, Fickel J, Hotzel H, Sachse K, Streich WJ, Wittstatt U, Frölich K. Newcastle disease virus and Chlamydia psittaci in free-living raptors from eastern Germany. Journal of Wildlife Diseases 2003;39:57-63.

Schettler E, Langgemach T, Sömmer P, Streich J, Frölich K. Seroepizootiology of selected infectious disease agents in free-living birds of prey in Germany. Journal of Wildlife Diseases 2001;37(1):145-152.

Sick H. Ornitologia brasileira. Rio de Janeiro: Ed. Nova Fronteira; 1997.862p.

Smith SA. Parasites of birds of prey: their diagnosis and treatment. Seminars in Avian and Exotic Pet Medicine 1996:5:97-105.

Valkiünas G. Avian malaria parasitesand other haemosporidia. Florida: CRC Press; 2005. 947p. 